\title{
Formulation and evaluation of multiple tablets as a biphasic gastroretentive floating drug delivery system for fenoverine
}

\author{
SURESH BANDARI \\ CHANDRA MOHAN EAGA \\ ASHOK THADISHETTY \\ MADHUSUDAN RAO YAMSANI* \\ Centre for Biopharmaceutics \\ and Pharmacokinetics, University \\ College of Pharmaceutical Sciences \\ Kakatiya University \\ Warangal-506009 (A.P.), India
}

\begin{abstract}
A biphasic gastroretentive drug delivery system of fenoverine was developed to maintain constant plasma concentration. The delivery system consisted of a loading-dose tablet and a floating multiple matrix tablet prepared by the direct compression process. The drug release from biphasic GRDDS in $0.1 \mathrm{~mol} \mathrm{~L}^{-1} \mathrm{HCl}$ and SGF (enzyme free) was sustained over $12 \mathrm{~h}$ with buoyant properties. Stability studies showed no significant change in dissolution profiles $(f 2$ value $>50)$. Based on the release kinetics, it can be concluded that the floating multiple matrix tablet containing HPMC was a particularly suitable gastroretentive drug delivery system with a zero-order release profile.
\end{abstract}

Keywords: biphasic release, gastroretention, multiple matrix tablet, release kinetics

A unique problem frequently encountered with the therapeutically advantageous oral sustained release dosage forms is their inability to reside in stomach and the proximal part of small intestine for a prolonged period of time. This led to the development of various gastroretentive drug delivery systems (GRDDS). The various approaches cited in the literature (1-4) include floatation, mucoadhesion, sedimentation, swelling or expansion, modified shape systems, or simultaneous administration of pharmacological agents that delay gastric emptying.

Among the various attempts made, the floating drug delivery systems offer the most effective and rational protection against early and random gastric emptying compared to the other methods proposed for prolonging the gastric residence time of solid dosage forms (4). However, the problems such as all or nothing emptying of single unit floating dosage forms made them unreliable and irreproducible in prolonging the gastric residence time, which led to the development of multiple unit floating systems (5). The development of mini-matrices is a promising area concerned with high control over the release rate of the drug combined with high flexibility of the adjustment of both the dose and the release of a drug or drugs (6). The concept of multiple units is characterized by

\footnotetext{
* Correspondence; e-mail: yamsani123@gmail.com
} 
S. Bandari et al.: Formulation and evaluation of multiple tablets as a biphasic gastroretentive floating drug delivery system for fenoverine, Acta Pharm. 60 (2010) 89-97.

the fact that the dose is administered as a number of subunits, each one containing the drug. The dose is then the sum of the quantity of the drug in each subunit and the functionality of the entire dose is directly correlated with the functionality of individual subunits (7). Like other multiple unit systems, multiple tablets can be filled into hard gelatin capsules that release these subunits after disintegration.

Fenoverine is an anti-spasmodic agent that restores smooth muscle motility and relieves the distressing symptoms associated with irritable bowel syndrome and primary dysmenorrhoea (8).

In the present study, biphasic GRDDS of fenoverine, as model drug, comprising an immediate release loading dose tablet (LDT) and sustained release floating multiple matrix tablets (FMMT) were developed and characterized for in vitro performance.

\section{EXPERIMENTAL}

\section{Materials}

Fenoverine and Spasmopriv ${ }^{\mathrm{TM}} 200 \mathrm{mg}$ capsules were generous gifts from Eurodrugs, India. HPMC K4M and HPMC 100 LV were obtained from ISP, India. Sodium bicarbonate, anhydrous citric acid and magnesium stearate were purchased from S.D. Fine-Chem Ltd, India. Purified talc was purchased from E. Merck, India. All other chemicals used were of analytical grade.

\section{Methods}

Preparation of the biphasic gastroretentive drug delivery system. - The total dose of fenoverine for twice daily sustained release formulation was calculated based on pharmacokinetic data (9). The loading dose and the maintainance dose were $74 \mathrm{mg}$ and $126 \mathrm{mg}$ of fenoverine, respectively. The total dose of GRDDS was $200 \mathrm{mg}$.

Preliminary formulations were studied to optimize the drug to polymer ratio and effervescent composition (data not shown). Then, the FMMT was prepared with an optimized concentration of effervescent composition. All formulation ingredients of FMMT and LDT were sifted through a $420-\mu \mathrm{m}$ aperture size sieve, homogeneously blended in a mortar separately and directly compressed using 6-mm flat punches on a rotary compression machine (Riddhi, India). The GRDDS marked 1, 2, 3, 4 comprising LDT and FMMT marked 1, 2, 3, 4 equivalent to $200 \mathrm{mg}$ of fenoverine, respectively, were placed in hard gelatin capsules size 0 and evaluated. The qualitative and quantitative composition of FMMT and LDT are shown in Table I.

Physical characterization of the blend and compressed FMMT and LDT. - Physical properties such as bulk density $(\rho b)$, tapped density $(\rho t)$, compressibility index and the angle of repose of the final blend of FMMT were determined.

Compressed multiple tablets were characterized for mass and thickness variation $(n=20)$. Crushing strength $(n=6)$ was measured with a Monsanto tester Campbell Electronics (India), friability $(n=6)$, with a Roche type friabilator. The drug content in 
S. Bandari et al.: Formulation and evaluation of multiple tablets as a biphasic gastroretentive floating drug delivery system for fenoverine, Acta Pharm. 60 (2010) 89-97.

Table I. Composition of the biphasic fenoverine gastroretentive drug delivery system

\begin{tabular}{lccccc}
\hline Ingredient (mg per tablet) & FMMT1 & FMMT2 & FMMT3 & FMMT4 & LDT \\
\hline Fenoverine & 42.00 & 42.00 & 42.00 & 42.00 & 74.00 \\
HPMC K 4M & 63.00 & 47.25 & 31.50 & 15.75 & - \\
HPMC K 100 LV & - & 15.75 & 31.50 & 47.25 & - \\
Sodium bicarbonate & 20.00 & 20.00 & 20.00 & 20.00 & - \\
Citric acid & 5.00 & 5.00 & 5.00 & 5.00 & - \\
Talc & 2.00 & 2.00 & 2.00 & 2.00 & 2.00 \\
Magnesium stearate & 2.00 & 2.00 & 2.00 & 2.00 & 2.00 \\
Cross caramellose sodium & - & - & - & - & 13.00 \\
Lactose & - & - & - & - & 44.00 \\
Total tablet mass (mg) & 134.00 & 134.00 & 134.00 & 134.00 & 135.00 \\
\hline
\end{tabular}

each formulation was determined by triturating 20 tablets in a mortar and powder equivalent to the average mass was added in $100 \mathrm{~mL}$ of $0.1 \mathrm{~mol} \mathrm{~L}^{-1}$ hydrochloric acid, followed by shaking for 30 minutes. The sample was analyzed by the HPLC method (10).

Tablet density. - The density of the tablets (in $\mathrm{g} \mathrm{cm}^{-3}$ ) was calculated from tablet height, diameter and mass using the equation:

$$
D=W /\left[(m / 2)^{2} \times \pi \times h\right]
$$

where $W$ is the mass of a tablet, $m$ is the tablet diameter, $\pi$ is the circular constant, and $h$ is the tablet height.

Floating behavior. - Buoyancy lag time and duration of buoyancy were determined in the USP dissolution apparatus II (11) with $0.1 \mathrm{~mol} \mathrm{~L}^{-1} \mathrm{HCl}$ and simulated gastric fluid (enzyme free SGF). The time between the tablet introduction into the medium and its buoyancy in the medium was taken as the buoyancy lag time and the duration of the tablet remaining buoyant was observed visually.

In vitro drug release studies. - The release of fenoverine from FMMT and biphasic GRDDS was studied using a USP (11) dissolution apparatus II (Labindia, India). The dissolution media were $900 \mathrm{~mL} 0.1 \mathrm{~mol} \mathrm{~L}^{-1} \mathrm{HCl}$ and SGF (enzyme free) maintained at $37 \pm 0.5^{\circ} \mathrm{C}$ and rotation speed of $50 \mathrm{rpm}$. Aliquots of $5 \mathrm{~mL}$ were collected at predetermined time intervals, filtered through a $0.45-\mu \mathrm{m}$ membrane filter and replenished with an equivalent volume of fresh medium. Drug contents in the samples were determined by HPLC after suitable dilutions.

Drug release modeling. - The suitability of several equations, reported in the literature to identify the mechanism(s) of fenoverine release $(12,13)$, was tested with respect to the release data.

The release profiles were compared by a statistically derived mathematical index, similarity factor (f2) (14) using theoretical profile as reference. The two dissolution pro- 
S. Bandari et al.: Formulation and evaluation of multiple tablets as a biphasic gastroretentive floating drug delivery system for fenoverine, Acta Pharm. 60 (2010) 89-97.

files are considered to be similar if $f 2$ value is higer than 50 (between 50 and 100). The dissolution efficiency $(D E)(15)$ at 2,6 and $8 \mathrm{~h}, t_{50 \%}$ and $t_{75 \%}$ were also determined from the dissolution profiles for each formulation.

Stability studies. - Optimized formulation was kept in the humidity chamber (LabTop, India) maintained at $40{ }^{\circ} \mathrm{C}$ and $75 \%$ relative humidity for 3 months. At the end of studies, the formulation was subjected to a drug assay, floating behavior testing and in vitro dissolution studies. For the comparison of release profiles of initial and aged samples, the similarity factor $f 2$ was calculated.

\section{RESULTS AND DISCUSSION}

\section{Physical properties of the final blend and compressed FMMT and LDT}

The floating multiple matrix tablets of fenoverine were prepared by the effervescent technique using methocel (K4M, K100LV). The combination of two different grades of HPMC was utilized to obtain the desired buoyant characteristics and to maintain the FMMT integrity for $12 \mathrm{~h}$. The blend of the final batches showed bulk density of $0.55 \pm 0.08$ $\mathrm{g} \mathrm{cm}^{-3}$ and tapped density of $0.64 \pm 0.10 \mathrm{~g} \mathrm{~cm}^{-3}$ indicating desirable flow properties. Further, the angle of repose showed a value of $<30^{\circ}$, compressibility below $15 \%$, indicating good flow properties of the formulations.

Physical characteristics of the loading dose tablet and floating multiple matrix tablets are shown in Table II. The drug content of FMMT and LDT was 101.1 \pm 1.1 and 100.4 $\pm 1.6 \%$, respectively $(n=3)$.

\section{Buoyancy and density}

The density of FMMT formulations was $1.202,1.195,1.225$ and $1.234 \mathrm{~g} \mathrm{~cm}^{-3}$, respectively. Though the density of formulated tablets was higher than $1.0 \mathrm{~g} \mathrm{~cm}^{-3}$, they remained buoyant for $12 \mathrm{~h}$ with a lag time of 4.16 to 5.22 minutes. The optimized concentration of the effervescent mixture (sodium bicarbonate and citric acid) contributed to the buoyancy of all tablets.

Table II. Physical characteristics of multiple tablets

\begin{tabular}{cccccc}
\hline Formulation & $\begin{array}{c}\text { Mass } \\
(\mathrm{mg})^{\mathrm{a}}\end{array}$ & $\begin{array}{c}\text { Crushing strength } \\
\left(\mathrm{kg} \mathrm{cm}^{-2}\right)^{\mathrm{b}}\end{array}$ & $\begin{array}{c}\text { Friability } \\
(\%)^{\mathrm{b}}\end{array}$ & $\begin{array}{c}\text { Drug content } \\
(\mathrm{mg})^{\mathrm{c}}\end{array}$ & $\begin{array}{c}\text { Floating lag time } \\
(\mathrm{min})^{\mathrm{c}}\end{array}$ \\
\hline FMMT1 & $134.3 \pm 1.0$ & $4.1 \pm 0.3$ & $0.8 \pm 0.1$ & $42.3 \pm 1.1$ & $4.16 \pm 0.3$ \\
FMMT2 & $133.5 \pm 1.6$ & $4.3 \pm 0.4$ & $0.6 \pm 0.1$ & $41.9 \pm 1.5$ & $5.22 \pm 0.7$ \\
FMMT3 & $135.4 \pm 1.7$ & $5.1 \pm 0.1$ & $0.5 \pm 0.1$ & $42.6 \pm 0.3$ & $4.93 \pm 0.3$ \\
FMMT4 & $136.0 \pm 2.2$ & $4.5 \pm 0.2$ & $0.6 \pm 0.1$ & $43.1 \pm 0.9$ & $4.74 \pm 0.6$ \\
LDT & $134.2 \pm 2.8$ & $5.3 \pm 0.3$ & $0.5 \pm 0.1$ & $74.3 \pm 1.6$ & - \\
\hline
\end{tabular}

Mean \pm SD: a $n=20$, b $n=6,{ }^{c} n=3$. 
S. Bandari et al.: Formulation and evaluation of multiple tablets as a biphasic gastroretentive floating drug delivery system for fenoverine, Acta Pharm. 60 (2010) 89-97.

\section{In vitro release studies}

Ideally, a sustained release formulation should release the required quantity of drug with predetermined kinetics in order to maintain an effective drug plasma concentration. To achieve this, the delivery system should be formulated so that it releases the drug in a predetermined and reproducible manner. The release of fenoverine from biphasic GRDDS was analyzed by plotting the cumulative percent drug released against time. Figs. 1a and b show the in vitro drug release profile of fenoverine in $0.1 \mathrm{~mol} \mathrm{~L}^{-1}$ $\mathrm{HCl}$ and SGF (enzyme free) from biphasic GRDDS. The biphasic GRDDS remains buoyant in dissolution media with liberation of FMMT and LDT after 10-15 minutes. There was an initial burst release of fenoverine from the gastroretentive system, which can be attributed to the LDT, and release of fenoverine from FMMT was sustained over $12 \mathrm{~h}$ compared to conventional commercial capsules which released the complete drug within 30 minutes. The initial burst release of $47.2 \pm 1.8 \%$ in $0.1 \mathrm{~mol} \mathrm{~L}^{-1} \mathrm{HCl}$ and $41.5 \pm 1.6 \%$ in SGF (enzyme free) from GRDDS was found during the first hour. The amount of drug released after $12 \mathrm{~h}\left(Q_{12}\right)$ from biphasic GRDDS was found to be $102.4 \pm 1.6 \%$ in $0.1 \mathrm{~mol}$ $\mathrm{L}^{-1} \mathrm{HCl}$ and $98.5 \pm 2.2 \%$ in SGF (enzyme free). The drug release from FMMT was sustained for a prolonged period of time due to the viscous nature of the HPMC matrix through which drug diffuses. Replacement of HPMC 100LV grade with HPMC K4M helped increase the drug release within $12 \mathrm{~h}$ and maintained the integrity and buoyancy of the FMMT formed. The increased drug release from FMMT with high concentration of HPMC K100LV compared to the FMMT containing its smaller amount may be due to matrix erosion in the former and swelling diffusion and a slight erosin mechanism in the latter. However, the matrix containing a high viscosity grade of polymer with large molecular mass mainly results in swelling properties with little erosion and vice versa. Integrity and floating properties of FMMT were thus maintained.
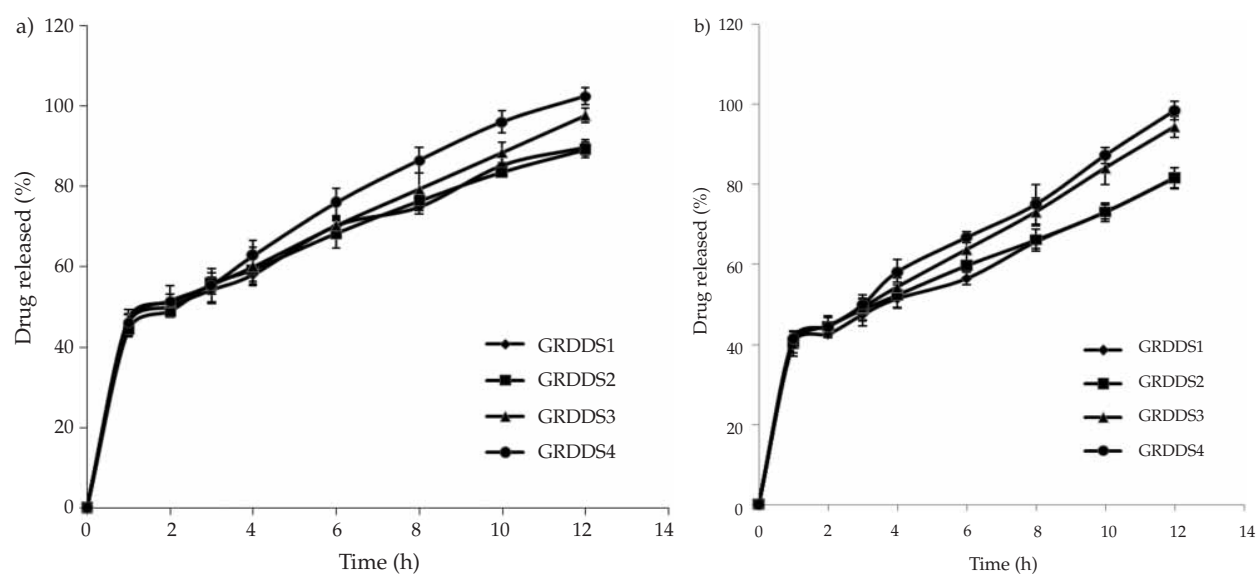

Fig. 1. Dissolution profiles of fenoverine from biphasic GRDDS in: a) $0.1 \mathrm{~mol} \mathrm{~L}^{-1} \mathrm{HCl}$, b) SGF (enzyme free) (mean $\pm \mathrm{SD}, n=6$ ). 
S. Bandari et al.: Formulation and evaluation of multiple tablets as a biphasic gastroretentive floating drug delivery system for fenoverine, Acta Pharm. 60 (2010) 89-97.

\section{Drug release pattern from GRDDS}

The results of kinetic models for fenoverine release from biphasic GRDDS are shown in Table III. The coefficient of determination $\left(R^{2}\right)$ was used as an indicator of the best fitting for each of the models considered. The results reveal that all formulations of biphasic GRDDS best fit in the zero-order model, in both $0.1 \mathrm{~mol} \mathrm{~L}^{-1} \mathrm{HCl}$ and SGF (enzyme free). The mechanism of drug release from these tablets was found to be diffusion, as seen from high $R^{2}$ values of the Higuchi model.

The optimized GRDDS formulation was selected based on the similarity factor (f2) values of all GRDDS and other dissolution parameters such as dissolution efficiency $(D E)$ at 2,6 and $8 \mathrm{~h}, t_{50 \%}$ and $t_{75 \%}$ and characteristics of GRDDS3 (Table IV). The similarity factor (f2) of GRDDS3, when compared to the theoretical release profile in $0.1 \mathrm{~mol} \mathrm{~L}^{-1}$ $\mathrm{HCl}$, was observed to be 91.5 , which was higher than for the other formulations, and 61.4 in SGF, which was well above 50 indicating that the drug release pattern was similar to the theoretical release profile. The other independent model parameters, such as dissolution efficiency, also revealed that the drug release profile from GRDDS3 was similar to the theoretical profile.

\section{Influence of media on drug release}

The fenoverine release in $12 \mathrm{~h}$ from optimized biphasic GRDDS3 in $0.1 \mathrm{~mol} \mathrm{~L}^{-1} \mathrm{HCl}$ and SGF (enzyme free) was found to be 97.7 and $94.4 \%$, respectively. $t$-Test indicated no statistically significant difference in drug release between the two media. However, the similarity factor (f2) of the drug release from GRDDS3 in $0.1 \mathrm{~mol} \mathrm{~L}^{-1} \mathrm{HCL}$ and SGF was found to be 59.4, thus indicating that the drug release in both media was similar.

Table III. In vitro release kinetics of fenoverine biphasic gastroretentive drug delivery systems

\begin{tabular}{|c|c|c|c|c|}
\hline \multirow{2}{*}{ Formulation } & \multirow{2}{*}{$\begin{array}{l}Q_{12} \text { release } \\
(\%)^{\mathrm{a}}\end{array}$} & \multicolumn{3}{|c|}{$R^{2}$} \\
\hline & & First-order & Zero-order & Higuchi \\
\hline \multicolumn{5}{|c|}{$0.1 \mathrm{~mol} \mathrm{~L}^{-1} \mathrm{HCl}$} \\
\hline GRDDS1 & $89.7 \pm 0.1$ & 0.975 & 0.990 & 0.980 \\
\hline GRDDS2 & $89.1 \pm 0.1$ & 0.965 & 0.990 & 0.994 \\
\hline GRDDS3 & $97.7 \pm 0.1$ & 0.991 & 0.999 & 0.974 \\
\hline GRDDS4 & $102.4 \pm 0.1$ & 0.970 & 0.991 & 0.983 \\
\hline \multicolumn{5}{|c|}{ SGF (enzyme free) } \\
\hline GRDDS1 & $81.7 \pm 1.1$ & 0.992 & 0.996 & 0.964 \\
\hline GRDDS2 & $81.6 \pm 0.4$ & 0.986 & 0.998 & 0.980 \\
\hline GRDDS3 & $94.4 \pm 0.2$ & 0.991 & 0.999 & 0.970 \\
\hline GRDDS4 & $98.5 \pm 0.3$ & 0.983 & 0.996 & 0.969 \\
\hline
\end{tabular}

a Drug released in $12 \mathrm{~h}$. Values represent mean $\pm \mathrm{SD}, n=3$. 
S. Bandari et al.: Formulation and evaluation of multiple tablets as a biphasic gastroretentive floating drug delivery system for fenoverine, Acta Pharm. 60 (2010) 89-97.

Table IV. Dissolution parameters and $f_{2}$ factor of GRDDS

\begin{tabular}{|c|c|c|c|c|c|c|}
\hline \multirow{2}{*}{ Formulation } & \multirow{2}{*}{$\begin{array}{c}t_{50 \%} \\
(\mathrm{~h})\end{array}$} & \multirow{2}{*}{$\begin{array}{c}t_{75 \%} \\
\text { (h) }\end{array}$} & \multicolumn{3}{|c|}{ DE $(\%)$} & \multirow{2}{*}{$f 2$ factor } \\
\hline & & & $2 \mathrm{~h}$ & $6 \mathrm{~h}$ & $8 \mathrm{~h}$ & \\
\hline \multicolumn{7}{|c|}{$0.1 \mathrm{~mol} \mathrm{~L}^{-1} \mathrm{HCl}$} \\
\hline Theoretical release & 2.0 & 7.0 & 50 & 70 & 80 & - \\
\hline GRDDS1 & 2.0 & 8.0 & 55.9 & 78.2 & 83.6 & 80 \\
\hline GRDDS2 & 2.1 & 7.6 & 55.0 & 76.6 & 85.8 & 85 \\
\hline GRDDS3 & 1.7 & 7.0 & 52.4 & 72.0 & 81.1 & 92 \\
\hline GRDDS4 & 1.6 & 5.8 & 50.2 & 74.1 & 84.5 & 70 \\
\hline \multicolumn{7}{|c|}{ SGF (enzyme free) } \\
\hline GRDDS1 & 3.6 & 10.4 & 52.1 & 69.2 & 80.4 & 50 \\
\hline GRDDS2 & 3.3 & 10.5 & 54.6 & 73.1 & 81.0 & 53 \\
\hline GRDDS3 & 3.0 & 8.3 & 47.2 & 67.5 & 77.5 & 61 \\
\hline GRDDS4 & 3.0 & 8.0 & 45.1 & 67.8 & 76.2 & 68 \\
\hline
\end{tabular}

$D E$ - dissolution efficiency

\section{Stability studies}

In view of the potential utility of the formulation, stability studies were carried out at $40{ }^{\circ} \mathrm{C}$ and $75 \% \mathrm{RH}$ for three months (for accelerated testing) to assess their long-term stability. Analysis of the dissolution data (Fig. 2), after storage for three months, showed no significant change in the release pattern indicating that the two dissolution profiles were similar $(f 2>50)$. The other parameters evaluated were comparable with initial values.

Fig. 2. Dissolution profile of GRDDS3 after storage at $40{ }^{\circ} \mathrm{C}$ and $75 \%$ RH (mean \pm SD, $n=$ 6).

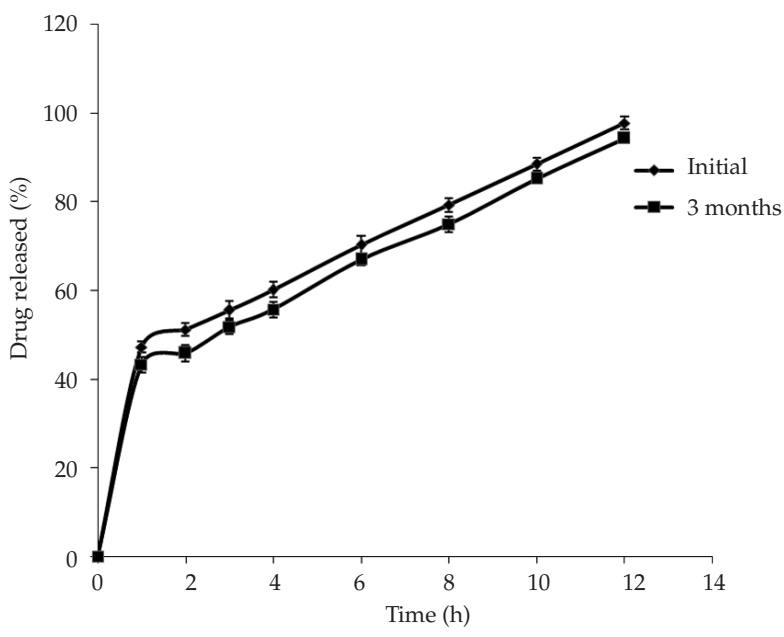


S. Bandari et al.: Formulation and evaluation of multiple tablets as a biphasic gastroretentive floating drug delivery system for fenoverine, Acta Pharm. 60 (2010) 89-97.

\section{CONCLUSIONS}

On the basis of buoyancy and in vitro release kinetics, it was concluded that the optimized formulation containing $200 \mathrm{mg}$ of fenoverine is a suitable GRDDS. FMMT was observed to be rigid, buoyant and initially showed no fragmentation because of its physical characteristics; it became soft at the end of the drug release studies. Biphasic GRDDS is characterized by the initial burst release (LDT) followed by a slow zero-order release pattern (FMMT) that shows high flexibility in modulating the delivery of the initial loading dose and the sustained dose. A further in vivo study has to be carried out to assess the bioavailability of the drug form biphasic GRDDS.

Acknowledgements. - B. Suresh is grateful to AICTE, New Delhi, India, for providing a National Doctoral Fellowship. The authors also thank B. Prabhashankar, Eurodrugs Laboratories, India, for his generous gifts of the fenoverine sample and Spasmopriv TM capsules.

\section{REFERENCES}

1. S. Hwang, H. Park and K. Park, Gastric retentive drug delivery systems, Crit. Rev. Ther. Drug Carrier Syst. 15 (1998) 243-284.

2. B. N. Singh and K. H. Kim, Floating drug delivery systems: An approach to oral controlled drug delivery via gastric retention, J. Control. Rel. 63 (2000) 235-259; DOI: 10.1016/S0168-3659(99)00204-7.

3. E. A. Klausner, E. Lavy, M. Friedman and A. Hoffman, Expandable gastroretentive dosage forms, J. Control. Rel. 90 (2003) 143-162; DOI: 10.1016/S0168-3659(03)00203-7.

4. A. J. Moes, Gastroretentive dosage forms, Crit. Rev. Ther. Drug Carrier Syst. 10 (1993) 143-195.

5. L. Meka, B. Kesavan, V. N. Kalamata, C. M. Eaga, S. Bandari, V. Vobalaboina and M. R. Yamsani, Design and evaluation of polymeric coated minitablets as multiple unit gastroretentive floating drug delivery systems for furosemide, J. Pharm. Sci. 98 (2009) 2122-2132; DOI: 10.1002/jps.21562.

6. R. Gandhi, C. L. Kaul and R. Panchagnula, Extrusion and spheronization in the development of oral controlled release dosage forms, Pharm. Sci. Tech. Today 2 (1999) 160-170; DOI: 10.1016/S1461-5347(99)00136-4.

7. A. Hoffman, M. Donbrow, S. T. Gross, S. Benita and R. Bahat, Fundamentals of release mechanism interpretation in multiparticulate systems: determination of substrate release from single microcapsules and relation between individual and ensemble release kinetics, Int. J. Pharm. 29 (1986) 195-211; DOI: 10.1016/0378-5173(86)90117-1.

8. G. David, J. C. Friedmann, E. Marmo and R. Pierre, Pharmacodynamic profile of fenoverine, a novel modulator of smooth muscle motility, Acta Ther. 12 (1986) 309-335.

9. A. M. Hamid, M. S. Harris, T. Jaweria and I. Y. Rabia, Once-daily tablet formulation and in vitro release evaluation of cefpodoxime using hydroxypropyl methylcellulose: A technical note, AAPS PharmSciTech. 7 (2006) Article 78.

10. S. Bandari, R. Gannu, K. V. S. Naidu and M. R. Yamsani, High performance liquid chromatographic determination of fenoverine in human serum: Application to pharmacokinetic study, J. Liq. Chrom. Rel. Tech. 31 (2008) 2101-2112; DOI: 10.1080/10826070802225379.

11. United States Pharmacopoeia 24/National Formulary 19, USO Convention, Rockville 2002.

12. P. Costa and J. M. Sousa Lobo, Modelling and comparison of dissolution profiles, Eur. J. Pharm. Sci. 13 (2001) 123-133; DOI: 10.1016/S0928-0987(01)00095-1. 
S. Bandari et al.: Formulation and evaluation of multiple tablets as a biphasic gastroretentive floating drug delivery system for fenoverine, Acta Pharm. 60 (2010) 89-97.

13. W. I. Higuchi, Analysis of data on the medicament release from ointments, J. Pharm. Sci. 51 (1962) 802-804.

14. J. W. Moore and H. H. Flanner, Mathematical comparison of dissolution profiles, Pharm. Tech. 20 (1996) 64-74.

15. K. A. Khan, The concept of dissolution efficiency, J. Pharm. Pharmacol. 27 (1975) 48-49.

\title{
$S A \check{Z} E T A K$
}

\section{Priprava i evaluacija dvofazičnih plutajućih tableta fenoverina}

\author{
SURESH BANDARI, CHANDRA MOHAN EAGA, ASHOK THADISHETTY i MADHUSUDAN RAO YAMSANI
}

U radu je opisan razvoj bifazičnog sustava za isporuku fenoverina s produljenim zadržavanjem u želucu radi održavanja konstantne koncentracije lijeka u plazmi. Sustav je dobiven metodom izravne kompresije, a sastoji se od tablete za inicijalno doziranje i matriksne tablete za plutanje. Oslobađanje lijeka iz bifazičnog GRDDS u 0,1 $\mathrm{mol} \mathrm{L}^{-1} \mathrm{HCl}$ i SGF (bez enzima) bilo je produljeno više od $12 \mathrm{~h}$, a sustav je pokazao plutajuća svojstva. Ispitivanja stabilnosti pokazala su da nema značajne promjene u profilu oslobađanja $(f 2>50)$. Na temelju kinetike oslobađanja može se zaključiti da su plutajuće višeslojne matriksne tablete s HPMC posebno pogodan sustav za isporuku fenoverina $u$ želucu $\mathrm{s}$ kinetikom oslobađanja nultog reda.

Ključne riječi: bifazično oslobađanje, zadržavanje u želucu, višeslojne matriksne tablete, kinetika oslobađanja

Centre for Biopharmaceutics and Pharmacokinetics, University College of Pharmaceutical Sciences Kakatiya University, Warangal-506 009 (A.P.), India 